\title{
The York Bakers and Their Play of the Last Supper
}

\begin{abstract}
This article reconsiders the York Bakers' pageant 'The Last Supper': both the play's representation of the biblical narrative and possible reasons for removal of a leaffrom the text as recorded in the York register. Noting the play's uninterrupted production throughout the protracted Reformation, I argue that the pageant likely represented the bread shared by Christ and his disciples as a common loaf rather than as eucharistic wafers. This style of representation makes sense of the pageant's guild ascription but challenges current assumptions about why dialogue and action were eventually excised from the written text of the play.
\end{abstract}

The compilation of the York Corpus Christi plays in British Library Additional MS 35290, more commonly referred to as the York register, began sometime between 1463 and 1477, likely closer to the latter date than to the former. ${ }^{1}$ The motivation behind the manuscript's creation is unknown; for some reason at this point in the cycle's history the city decided it should preserve and further regulate the plays as a civic cultural artefact. ${ }^{2}$ The property of the city council, or 'corporation', of York and the charge of its common clerk, the manuscript preserved the city's Corpus Christi pageants as they were performed in and around the 1470s. The register also recorded evidence of subsequent changes to the plays in the form of later clerical annotations in its margins. These notes were added perhaps from the creation of the manuscript, but almost certainly from the beginning of the sixteenth century, as the common clerk sat at the plays' first performance station, the gates of Holy Trinity Priory, and compared the written texts as transcribed into the register with the pageants' performed dialogue and action. Later, the manuscript assumed at least one other important function as external and internal threats during the protracted crisis of the English Reformation made the review, revision, and suspension of individual plays within the manuscript necessary to the continued performance of the cycle. ${ }^{3}$

Leanne Groeneveld (Leanne.Groeneveld@uregina.ca) is associate professor of theatre studies at Campion College, University of Regina, SK. 
One single and five conjugate leaves are missing from the register. Some losses were likely accidental while others were probably intentional. ${ }^{4}$ Who made the latter deliberate excisions, as well as when and why they were made, cannot be determined. Richard Beadle has observed that the manuscript lacks clear marginal annotations suggesting the texts were problematic in these sections. ${ }^{5}$ In some instances, however, plays were possibly judged sufficiently defective that leaves were removed in anticipation of new transcriptions (not completed) needed to record observed changes to the plays in performance. In other instances it seems possible that some censoring authority made excisions either in preparation for revision of problematic sections of dialogue and action, or to remove problematic sections with no intention to revise and replace them. In the latter case, the removal of a leaf may have served symbolically to withdraw and retire a particular play within the larger cycle or, as I will suggest, may have served to decommission the whole register as a production document if taken from a play considered central to the cycle's continued performance.

Exactly what a censor may have considered problematic and therefore in need of future revision in most of the affected plays is not immediately apparent, even considering the context of the York Corpus Christi cycle's final decades and eventual demise: the religious controversies of the mid-to-late sixteenth century and, more specifically, the central government's targeted campaign to reform the north after the uprising of the northern earls in $1569 .{ }^{6}$ Why the Bakers' play 'The Last Supper' may have had its central section removed, however, is easier to imagine. A representation of the 'historical' Last Supper and the institution of the sacrament of the mass, the play almost certainly would have attracted careful attention during periods of political transition and more enthusiastic reform. In his earlier edition of the plays, Beadle suggests that the leaf missing from quire $\mathrm{R}$ could have been 'deliberately removed during the religious controversies of the sixteenth century'7; in his later edition, he more cautiously writes, "Whether some aspect of their presentation [of the institution of the mass and first celebration of communion] prompted the deliberate removal of the leaf on which they appeared, perhaps in the changing religious climate of the later sixteenth century, can only be a matter for speculation' 8

One possible explanation for the excision could be that the pageant represented the event of the Last Supper as a traditional eucharistic celebration of the sacrament, a representation eventually problematic to authorities with reformed sensibilities and agendas. I argue, however, that the York play 'The Last Supper' likely dramatized this moment less as a sacrament than as the historical origin of that sacrament described in gospel accounts: the meal Christ shared with his disciples. 
The guild responsible for the play's production, the Bakers, undoubtedly carefully considered their choice of properties, most importantly the bread presented on stage; whatever they used likely related to and reflected well on their craft, its long history, as well as its contemporary position within the community. I suspect that throughout their pageant's history the Bakers represented the bread using a loaf or loaves rather than eucharistic wafers; by featuring their own product, they asserted their place in the social, political, and devotional culture of York. This staging could explain the pageant's continued performance when other plays were removed from production because they were religiously contentious and provocative. The choice to dramatize the historical origin rather than any particular ritual expression of the sacrament would have allowed multiple, even contradictory readings of the play's Last Supper: as the historical prototype of a traditional and (trans)substantive sacrament or as the moment referenced in a strictly memorial and figurative sacrament.

As Beadle has cautioned, because of the manuscript's lacuna, exactly how 'The Last Supper' was staged in York must remain a subject of speculation. Clifford Davidson as well as Nicole R. Rice and Margaret Aziza Pappano have conjectured that the play represented its central dramatic action as a traditional celebration of the mass. Davidson's inspiration for his imagined staging of the play is a midfourteenth-century panel of stained glass - which predates the first reference, in 1376, to Corpus Christi plays in York by several decades - located in the choir of York Minster: 'In the Last Supper panel, Jesus is centrally placed and blessing with his right hand, while with the left he reaches out toward a dish on the cloth-covered table. The apostles are located on each side ... A chalice and a ciborium, with hosts, stand on the table.' Davidson elsewhere notes that in the glass, and therefore he seems to conclude in the play, 'heavy emphasis is placed on the institution of the Eucharist, with the table setting and action designed to provide a direct link to the Canon of the Mass and Communion..${ }^{10}$ Rice and Pappano suggest further that a priest may have represented Christ, as the role was 'large' and was 'probably accompanied by some liturgical actions in the missing scene. ${ }^{11}$

If the Bakers' play depicted the Last Supper as Davidson, Rice, and Pappano have argued, the leaf's eventual removal from quire $\mathrm{R}$ makes obvious sense. For a number of decades in the sixteenth century, the kinds of liturgical vessels used for the celebration of the mass in parish churches became a contentious issue, conflict brewing between reformers and conservatives. The first edition of the Book of Common Prayer in 1549 expressed ambivalence about type, directing those ministering communion to lay the bread 'upon the corporas, or els in the paten, or in some other comely thyng, prepared for that purpose' and to put 
the wine 'into the Chalice, or els in some faire or conveniente cup, prepared for that use. ${ }^{12}$ The Edwardian regime's initial ambivalence later progressed to confiscation of parish church plate and other goods, partly motivated by religious zeal, partly motivated by economic need; on 3 March 1550/51, the Privy Council issued a decree that 'forasmuche as the Kinges Majestie had neede presently of a masse of mooney, therfore Commissions shulde be addressed into all shires of Englande to take into the Kinges handes suche churche plate as remaigneth, to be emploied unto his Highnes use'. ${ }^{13}$ Alexandra Walsham describes a subsequent 'extraordinary campaign of expropriation that culminated in 1552': inventories were taken of all church plate and furniture, including 'silver and gilt chalices and other vessels, candlesticks, ornaments, copes, cloths, and bells possessed by every parish, together with estimates of their monetary value.'. ${ }^{14}$ According to Claire Cross, in the specific case of York, 'Apart from a single chalice, all the plate and the jewels remaining in the parish churches ... were confiscated by the state later in [Edward's] reign'. 15

When Mary came to the throne, some items were returned, replaced, or, because initially hidden from state authorities, restored to use in the liturgy. ${ }^{16}$ With Mary's death and Elizabeth's ascension, however, it was 'hardly open to doubt' that England would return to the liturgy and recommended practice set out in the Book of Common Prayer ${ }^{17}$ and this return would again affect the plate used in parish churches. In York, in anticipation of change, a donor ordered a communion cup from a London maker for the parish church St. Michael le Belfrey; its 1558/59 hallmark indicates that at least some citizens felt early enthusiasm for a return to - and perhaps expansion of - Edwardian religious reforms. ${ }^{18}$ Elizabeth did not follow Edward's example and confiscate the Marian church plate, likely aware that little profit would ensue from the small amount remaining in or restored to churches, choosing instead to leave decisions about liturgical vessels to ecclesiastical authorities. ${ }^{19}$ The 1559 Book of Common Prayer said nothing about preferred type, and the use of chalices continued alongside that of larger and less ornate communion cups, leading to mixed practice among parishes. Chalices were only proscribed in 1571 when Archbishop of York Edmund Grindal specified in his injunctions to the clergy that they should 'minister the Holy communion in no challice, nor any prophane cup or glasse, but in a Communion cup of Siluer, and with a couer of Siluer.'. 20

Still more contentious, the 1552 and 1559 editions of the Book of Common Prayer proscribed the use of eucharistic wafers in the celebration of the mass, calling instead for loaves of bread: 'And to take awaye the superstition, whiche any person hath, or myghte have in the breade and wyne, it shall suffice that the 
breade be suche as is usual to be eaten at the table, with other meates, but the beste and purest wheate breade, that conveniently may be gotten'. ${ }^{21}$ As though to confuse the issue, royal injunctions in 1559 subsequently contradicted the Book of Prayer, requiring wafers for communion. ${ }^{22}$ This inconsistency resulted in controversy and mixed practice in English parishes at the time and through the 1560s and 1570 s, partly because of initial uncertainty about which directive was legally binding. Adding to the confusion, the new prayer book was not repealed and did not undergo revision in subsequent printings. ${ }^{23}$ According to James F. Turrell, 'A number of bishops sought to enforce the use of wafers, which was abhorrent to puritans and more energetic Evangelicals, while in some parishes the use of ordinary bread caused the more traditional-minded to complain'. ${ }^{24}$

During an extended period of time, then, beginning at least by 1549 , celebrations of the mass - and therefore presumably dramatic representations of the celebration of the mass - using either chalice or communion cup, either wafers or bread, from either reformed or conservative perspectives, generated controversy and inspired complaints. Surviving records, however, show little indication that York, any of its citizens, or the Bakers' guild worried that performances of the Last Supper might be considered religiously problematic and therefore politically dangerous. The Bakers' account books for 1544-80 survive, ${ }^{25}$ and these records by and large cover the time period in which 'The Last Supper' most likely would have experienced censorship if judged in any way suspect. During this same period, the city government removed other plays considered contentious from the cycle in performance although, significantly, their texts remain in the register: in 1548 and 1561, 'The Dying', 'Assumption', and 'Coronation of our Lady' were shelved before and after being restored from 1554 to 1557, when Mary was on the throne. ${ }^{26}$ In contrast, the corporation apparently considered the Bakers' play religiously unproblematic and centrally important: in 1551, 'The Last Supper' formed part of a shortened cycle of only ten plays, the production downsized because of a recent outbreak of an unidentified illness. ${ }^{27}$ York did not stage plays in 1558, 'the tyme instant beyng bothe trowblouse with warres and also contagiouse with sykenesse', ${ }^{28}$ although the 'Pater Noster' play may have been performed instead. And no performance seems to have taken place in 1559 or 1560. After 1561, performances of the Corpus Christi plays became less regular but continued: the cycle was performed in 1562 (perhaps), 1563, 1567, and 1569. ${ }^{29}$ The Bakers' records are missing for 1562 but indicate that they participated in all of these other productions. Only one documented objection to the performance of the Bakers' play survives: in 1554, Nicholas Haxop, a member of the guild, was fined $40 \mathrm{~d}$ for disobeying the guild's searchers and, having been warned, refusing to attend the 
Bakers' play in $1554 .{ }^{30}$ Alexandra Johnston suggests that this action was 'possibly motivated by Protestant zeal'. ${ }^{31}$ Haxop's zeal need not have been directed against the play's style of representation, however; it as likely could have been directed against the celebration of Corpus Christi as a feast day. That other bakers did not act similarly, expressing either reformed or conservative sentiments, seems striking given the potentially provocative subject matter of the Bakers' pageant.

Evidence of greater opposition to, suppression of, and revision of plays in response to religious controversy survives in centres such as Coventry, Norwich, and Chester, including suppression and revision of the latter's depiction of the Last Supper. ${ }^{32}$ How might a late medieval play depicting the institution of the sacrament of the mass have continued, as apparently the York play did, largely unchallenged, unchanged, and uninterrupted through its early modern performance history?

The conservatism of York perhaps played a part in the pageant's longevity. To some degree the city resisted making concessions to demands for religious change originating with the crown in the south; for example, the cycle continued to be performed on Corpus Christi even after the feast day was officially abolished in 1548. Yet in other cases York civic authorities enacted what Norman Jones has termed 'observable behaviors that conformed to the Church's mandates'. ${ }^{33}$ Jones argues that individuals (therefore secular political and religious institutions) navigating the Reformation in England more often asked "What do I do now?" than "What do I believe now?" when authorities issued new injunctions. ${ }^{34}$ A.G. Dickens has noted a general conformity of religious authorities in the county of Yorkshire and city of York to Edwardian reforms, ${ }^{35}$ while Ethan H. Shagan has suggested that in England 'the Reformation was a muddled process in which action often preceded self-conscious theologising or identity formation'. ${ }^{36}$ Whatever their personal convictions, the mayor and council of York demonstrated a pragmatic willingness to conform through their observable behaviours in the suspension of the Mary pageants at the accessions of Edward and (eventually) Elizabeth. The restitution of these plays during Mary's reign further constituted not simply a renewed expression of temporarily suppressed devotion but also a canny political move: the plays dramatized central moments in the biography of the religious figure for whom the new queen had been named.

The York 'Last Supper' play's uninterrupted performance history may have had quite a lot to do with the fact, mentioned above, that every production of the city's cycle for which records survive, with the exception of its final performance in 1569, took place on the feast of Corpus Christi. It would seem problematic to remove 'The Last Supper' from a production designed for performance on a feast 
day that celebrated the institution of the sacrament of the mass and the miracle of transubstantiation; this excision would remove the cycle's reason for existence, its core. Staging a cycle of plays with 'The Last Supper' at its centre on any other feast day would, conversely, make little sense, explaining in part the city's commitment to the timing of the production. ${ }^{37}$ For comparison, the city of Chester's cycle was presented instead at Whitsun (at least from ca 1520/21); production during this feast perhaps allowed the city to suspend the Chester Bakers' 'Last Supper' by 1550 . This suspension roughly coincided with Edward VI's accession and the publication of the first Book of Common Prayer, and lasted until as late as 1561. During this period the Chester Bakers did not perform their pageant; the Shoemakers instead presented a play dramatizing events from Christ's entry into Jerusalem through to his capture. In this form, as part of an expanded sequence of events and actions, the Last Supper episode certainly would have drawn less focus. Paul Whitfield White has proposed that the Bakers' original play 'The Last Supper' was considered problematic beginning in Edward VI's reign and was 'likely suppressed around this time, perhaps because ... it espoused transubstantiation'. ${ }^{38}$

Eventually the city retired the Chester Shoemakers' longer play, and the Bakers once again began performing a separate pageant. What their reinstated play looked like is uncertain, but 'The Last Supper' recorded in the cycle's extant manuscripts seems itself to be a revision. Whitfield White notes that the surviving text 'reflects a Protestant view of the Eucharist'. Chester's Late Banns, which 'announce the plays as a fully Protestantized cycle', 'warn the [Bakers] guild that any interpretation of the Last Supper as evidence of the real presence in the Eucharist, probably the type of language that got the pageant temporarily suppressed under Edward VI, would be to court controversy'39: 'yow Bakers see yat with the same wordes you vtter / As Criste himselfe spake them to be a memorall / Of yat deathe \& passion within playe after ensue shall'. ${ }^{40}$ Erin E. Kelly has remarked, 'The climactic moment of the performance features the player portraying Jesus breaking and distributing bread in a way that more closely resembles what some radical reformers unsuccessfully argued should be regular practice in the Elizabethan church than any Catholic ritual'. 41 Theodore Lerud believes that the Chester play of the Last Supper was substantially revised to make the play's representation conform to the 1549 and/or 1552 Book of Common Prayer, echoing their language around the celebration of the sacrament. ${ }^{42}$

The 'reformed' nature of the Chester play is relevant to the puzzle of the York 'Last Supper' given certain similarities evident between the two texts. First, both dramatize the celebration of the supper and institution of the sacrament remarkably concisely. The section currently missing from the York play according to 
Beadle likely contained fifty-three lines: seven lines to finish a fragmentary stanza at 85 in which Christ presents a child as an example of faith to his disciples, three complete stanzas of twelve lines each, and ten lines to complete a stanza that ends at 91 containing Christ and Judas's exchange about the sop and about the latter's betrayal. ${ }^{43}$ At most, the supper proper would have unfolded over three twelve-line stanzas, just thirty-six lines, given the other events framing this action. Beadle observes, 'The institution of the sacrament and the first communion seem to have been presented quite succinctly, notwithstanding their significance in relation to the occasion of the Corpus Christi Play as a whole'. ${ }^{44}$ York's 'The Last Supper' could not have resembled its equivalent dramatic sequence in N-Town's 'Passion Play 1', a play not produced by a craft guild nor as part of a larger cycle of plays performed together yearly. The latter dramatization, which clearly uses wafers to represent the bread, covers just over one hundred lines of dialogue and offers elaborate typological readings of the discontinued Passover meal against the new sacrament instituted by Christ. ${ }^{45}$ The missing section in York more likely resembled its equivalent in the Chester cycle, in which the institution of the sacrament covers approximately five eight-line stanzas (forty lines).

Second, although all three plays represent the revelation of Judas's betrayal through the incident with the sop, in which Judas dips his hand into Christ's dish (Matthew 26.23, Mark 14.20) or receives bread dipped by Christ in his own dish (John 13.26), the timing differs. In N-Town, Judas dips his bread in Christ's dish after the paschal meal; Christ informs the disciples at this point in the action, 'In my dysche he etyht pis treson xal begynne. ${ }^{46}$ The paschal meal of lamb occurs first in the dramatic sequence, divided from the later institution of the new sacrament and Christ's communion with the disciples by Judas's exit, betrayal of Christ to the high priests, and return to the table. Only once Judas returns does he communicate with the other apostles after Christ asks, 'Judas, art pu avysyd what pu xalt take? ${ }^{47}$ In contrast, in Chester Judas dips his bread in Christ's dish after, not before, Christ and the disciples celebrate communion. According to the play's stage directions, Christ 'accipiet panem, frangit, et discipulis suis dat' (takes the bread, breaks it, and gives it to his disciples); 48 he blesses the bread and later the wine; 'Tunc edit et bibit cum discipulis, et Judas Iscarioth habebit manum in patina' (then he eats and drinks with the disciples, and Judas Iscariot places his hand in the dish). ${ }^{49}$ Christ reveals his betrayer, saying, 'Through his deceipte I am but dead / that in my cuppe weetes his bread'; 'Tunc Judas intingit in patinam' (Then Judas dips [bread] in the dish). ${ }^{50}$ In York's 'The Last Supper' the timing must be similar to Chester's. Christ celebrates the paschal feast at the beginning of the action, telling the disciples that he will 'parte' the lamb himself and distribute it 
among them. ${ }^{51}$ The meal complete, Christ then proscribes its consumption 'Euere forward'. ${ }^{52}$ He begins a new law that presumably instead involves the division and distribution of bread. The communion itself is missing but it likely concluded with some variation on the incident with the sop. The moment could be dramatized in a number of ways: by following Matthew and Mark, by following John, or by harmonizing the accounts. Beadle in his notes assumes the play followed John but does not explain why; ${ }^{53}$ perhaps he makes this assumption because the first lines in the text after the lacuna are 'Quod facis, fac cicius: / Pat pou schall do, do sone. ${ }^{54}$ This command is found only in John; however, Chester includes it after Judas dips his own bread in Christ's dish, following Matthew and Mark: Christ tells Judas, 'That thou shalt doe, doe hastelye. ${ }^{55}$ In N-Town, the line of dialogue is placed after Judas communicates: 'Pat pu hast begonne', Christ commands Judas, 'brenge to an ende. ${ }^{56}$ These plays then harmonize the gospel versions of the event, as, likely, the York play would have done.

The timing of the incident with the sop is significant. In N-Town, the bread Judas dips is clearly not communion bread; in Chester and York, it appears to be. This distinction perhaps indicates the nature of the bread used in performance. According to Lynette Muir, although a number of English and continental dramatizations of the Last Supper specify that wafers should be used to represent communion bread on stage, most distinguish those wafers from the bread Judas dips in the sop. ${ }^{57}$ Only in La Passion de Semur is a host apparently used for this purpose. The stage directions describe the bread as 'hostias pulcras et rotondas' (fair round hosts). After communion, Christ 'intingat panem in vinum et tradat Jude' (dips the bread in the wine and gives it to Judas), and likely dips a host into the chalice he has blessed. ${ }^{58}$ This action, following John, differs from the dramatized versions in extant English plays and therefore probably differs from the representation in York. It seems equally improbable that in York Judas handled a communion wafer so casually as to dip it himself into Christ's bowl or cup.

So how might the missing section of play have represented the Last Supper? To begin, the vessels used as stage properties likely did not resemble church plate. Although in the extant Bakers' accounts expenses periodically appear for the 'payntyng of ... dyodyms' worn by the disciples (presumably gilded or painted gold), 59 no expenses are noted for the painting of a stage property chalice or ciborium. Anna Mill concluded from the records that the York 'Last Supper' 'demanded ... merely simple utensils such as any honest craftsman's household could furnish at need'. ${ }^{60}$ These 'simple utensils' would not court controversy during periods of religious instability — but only if the Last Supper were depicted as the historical meal described in gospel accounts and not as a contemporary church sacrament; 
their simplicity in the latter case would trouble conservatives. This style of representation would depend as much, if not more, on the depiction of the bread blessed by Christ and shared with the apostles. None of the critics discussed above who argue the reformed nature of the Chester Bakers' play offer an opinion on how that pageant represented the 'panem' called for in its stage directions; however, if, as Lerud asserts, the 1552 Book of Common Prayer influenced the play's revisions, the bread used must have been a 'common' loaf. The York 'Last Supper', at least from the time of its pre-Reformation transcription into the York register through to the end of the cycle as a civic production, ${ }^{61}$ could have represented its bread similarly and in consequence later appeared theologically neutral.

If represented by a loaf, the bread as central property would make better sense of the pageant's guild ascription. Bakers, at least as part of their sanctioned work, do not appear to have produced wafers for secular consumption or for consecration and use in English churches. The York Bakers' and civic ordinances specify the types of bread produced by the guild: wastel, simnel, payndemayne or demesne, and cocket. They also produced flat or unleavened loaves which likely resembled the oven-bottom cakes traditional to Yorkshire. ${ }^{62}$ These breads required the high, sustained, and consistent heat of ovens, which were present in some buildings but not in others. To ply their trades, cooks and bakers needed to own or secure access to ovens which they then fired and maintained, 'a dirty, time-consuming and expensive operation'. ${ }^{63}$ 'Wafers' or 'wafer-cakes', 'very light thin crisp cake[s]', were 'baked between wafer-irons'; 64 all that was needed by those who made wafers was a heat source, a fire, fireplace, or hot embers. In England a distinct group of artisans separate from the Bakers' guild known as 'waferers' produced the secular wafers traditionally served at the end of elaborate dinners and on special occasions; ${ }^{65}$ whether or not they produced wafers meant for consecration is unclear. ${ }^{66}$ Artisans in England may have specialized in producing one kind or the other, or produced both; however, the latter seems unlikely as secular waferers suffered poor reputations, ${ }^{67}$ especially when itinerant victuallers, who were lumped together with travelling entertainers and 'listed alongside players in statutes regulating "rogues" and "vagabonds". 68

Henry Philibert Feasey believed that wafers used in parish churches were generally produced by priests. ${ }^{69}$ Miri Rubin notes a parish priest's fifteenth-century workbook containing a recipe for eucharistic wafers; she suggests that hosts were made in the recesses of parish churches, some of which had flues. ${ }^{70}$ Clergy and religious in England, however, may have hired local parishioners or artisans to help when in-house production of wafers could not supply demand. Women in particular possibly served a role assisting clergy in this way, either for pay or as an 
act of parish service. A late fifteenth-century Dominican Easter sermon reports, 'per was onys a good woman in Rome that, azenst every Sonday, sche made a certen of obleys and brow3te hem to seynt Gregori in maner of an offeryng, of the whiche seynt Gregori made Goddis body on the awtur'. ${ }^{71}$ The situation in larger churches and cathedrals may have been more complicated. The Fabric Rolls record expenses for wafers used in the liturgies at York Minster in multiple years: 1371, 'In iiij.m. wafris, 7s. 4d.'; 1375, 'Pro iiij.m wafers emptis pro choro [purchased for the choir], 7s. 8d.'; and circa 1550, 'For ij thowsaund singingbreade [communion wafers] spent this half yeare, $16 \mathrm{~d} .{ }^{\prime}{ }^{72}$ These amounts may record the cost of inhouse production; however, the York minster treasurer may have purchased wafers directly from local artisans or through middle men: the 1519 inventory of a shopkeeper in Kirton in Lindsey included among many other items 'a kettyll', 'A Candylstyke', 'j dosan playng cards', and 'Syngyngbred'. ${ }^{73}$ Exactly who supplied the shopkeeper with wafers is nowhere specified. No evidence remains, however, to suggest that the Bakers engaged in this production. ${ }^{74}$

The York Bakers may have chosen to represent the bread shared by Christ and his disciples as a loaf to showcase their craft and advertise its main product. This choice may have given them further opportunity to assert their historical place within and contemporary right to participate in a ritual from which they had been barred 'except as observers', as Tony Corbett has argued: the Corpus Christi plays 'can be seen as an attempt by the laity to compensate for their exclusion from the official Liturgy. ${ }^{75}$ By tracing the origins of the eucharist to an historical loaf, the Bakers' play perhaps participated in what Sarah Beckwith has described as 'an artisanal ideology' in the plays, one that 'placed importance on manufacture, or on making, rather than on the control of exchange mechanisms, through the manipulation of networks of supply and distribution'. ${ }^{76}$ Civic authorities controlled the city's distribution networks - merchants largely populated the mayoralty and the city council in York - and religious authorities controlled distribution of and therefore access to the sacraments. The bakers additionally would have been concerned to distinguish themselves from unskilled workers: Rice and Pappano paint a convincing portrait of 'the master craftsman as a figure who is not only struggling against merchant power but also differentiating himself from unenfranchised laborers, developing a specific agenda that takes as its basis claims to local civic identification, membership in the city franchise, and particular forms of skill'.77 It seems unlikely that the York Bakers would feature in their pageant the work of unskilled and unenfranchised waferers or of women assisting their parish priests. 
The Bakers' play, if it used a loaf of bread to represent the first communion depicted in the gospels, reminded audiences that the bread Christ broke and shared with his disciples was a loaf originally produced by craftsmen. The Bakers fashioned and controlled their most important stage property, a commodity for purchase directly from them with no merchant intermediaries. Bread was also an object of charity regularly produced and distributed by the Bakers, symbolic of their social position and function in York supplying a basic food stuff, not only or always for purchase. Their records document charitable expenses they incurred, for example, 'yat day yat we mayd mandy bred' (in $1549,4 \mathrm{~d}$ ), ${ }^{78}$ bread meant for distribution to the poor on Maundy Thursday. This act of almsgiving occurred perhaps in connection with a ceremonial washing of the poor's feet, ${ }^{79}$ suggesting that the Bakers' devotion to the Last Supper extended beyond their play and its performance. ${ }^{80}$ Before the Reformation, the bread on stage could also have referenced other important social practices and rituals - for example, the sharing of the holy loaf at the conclusion of the mass in local parish churches, which Eamon Duffy pronounces an 'obvious substitute for lay communion':

A loaf of bread presented by one of the householders of the parish was solemnly blessed, cut up in a skip or basket, and distributed to the congregation. The offering of this loaf, which was regulated by a rota, was attended with considerable solemnity, the provider processing to the high altar before matins, reciting a special prayer, and offering a candle to the priest at the same time. It was usual for the curate to pray explicitly 'for the good man or woman that this day geveth bread to make the holy lofe' when he bid the bedes. This holy loaf was meant to be the first food one tasted on a Sunday; eaten or simply carried in one's pocket, it was believed to have apotropaic powers. If one died without a priest, reception of holy bread was accounted a sufficient substitute for housel. ${ }^{81}$

Although a priest sanctified the bread and the church maintained control of it through the parish rota and the bread's distribution, the holy loaf began and often continued its social life outside the church. Produced by the laity and given over to the church by one of its members, the loaf spent only a brief time within Beckwith's official religious 'exchange mechanism'; after, eaten or carried away in a pocket, even though un-transubstantiated, a piece of this loaf conferred many of the benefits gained by viewing the eucharist at mass. Before the Reformation, then, the 'corpus Christi' represented within the Bakers' play was not one exclusively produced and controlled by the church. ${ }^{82}$ 
The choice to use a loaf of bread on their stage, both before and during the Reformation, would have allowed the Bakers simultaneously to celebrate the subject matter of their play, their part in the production of the cycle, their craft, the artisan's role in divine history, and their contemporary social role within the city. To complicate readings of the loaf still further, however, before, during, and after the Reformation, Christ's division and sharing of bread in the York Bakers' play potentially also worked against any 'artisanal ideology' it promoted. Meisha Lohmann has agreed with Beckwith that the York cycle was 'an opportunity for guilds opposed to mercantile power to present narratives challenging the merchant elite's right to rule. ${ }^{83}$ She has argued as well, however, that 'financial stability was integral to the creation of the York Corpus Christi Cycle' and that 'several plays in the cycle insist on the central importance of economic success to York's civic drama by acknowledging the primary source of York's economic prosperity — overseas trade — and by endorsing or indicting the political climate created by the primacy of trade in the city's economy'. 'Some plays' therefore 'call upon ancient biblical authority to legitimize the newly formed civic power of merchants'. ${ }^{84}$ The individual plays in the cycle express clashing ideologies.

Lohmann does not discuss the play 'The Last Supper' in her article. The Bakers produced perishable goods for local consumption only. They likely did not rely heavily on foreign imports to supply their trade, as, for example, did the Goldsmiths, who produced a corporation-friendly play of the Magi. ${ }^{85}$ Bakers did, however, require access to spices, as noted below. Also, Bakers were subject to national legislation: the royal Assize of Bread, which from the late twelfth century established a fixed price for types and weights of bread depending on the price of grain. Violations resulted in fines; the Assize was enforced by the corporation and, as Heather Swanson points out, 'was potentially a very fine revenue-raiser, as well as being a means for enforcing standards'. ${ }^{86}$ Not only quality but quantity was surveilled: when in 1485 the corporation determined that the Bakers had not produced sufficient bread for the commons of the city, it collectively fined them. ${ }^{87}$

Subject to such scrutiny, the Bakers, like the Goldsmiths, may have felt a need to flatter and 'legitimize' the corporation in their play as well as in the specific context of its production. In her analysis of the Bakers' accounts, Mill notes a regular Corpus Christi day expense somewhere between 8 and 12d incurred by the Bakers from 1542 until 1569, 88 the years of pageant production covered in their extant records. At Corpus Christi, the Bakers provided to the mayor and councillors a 'shield', sometimes two shields, of something called 'mayne bread'. Dr Almute Grohmann-Sinz has reconstructed a possible recipe for this 'bread', concluding that it was a molded biscuit similar to the German springerle made 
with eggs, sugar, coriander, caraway seeds, and rose water. ${ }^{89}$ It therefore would not have resembled either a wafer or the loaf of bread likely shared by Christ and his apostles in the play. The description of the 'bread' as a 'shield' probably indicates its molded shape, the city's coat of arms ('shield' or escutcheon). ${ }^{90}$ The Bakers presented their mayne bread to the mayor, presumably for him to share with his twelve councillors as they watched the cycle together. Jesse Njus observes, 'The fact that medieval audiences were certainly allowed to eat during productions might have heightened the sensation of the communal meal for any audience members who chose to eat during the Last Supper. ${ }^{91}$ In York's case, the corporation's practice of sharing mayne bread while watching the Bakers' performance could have encouraged comparison of the mayor and councillors with Christ and his twelve disciples as represented in the pageant, even if only in the former's own minds. After all, both groups of men together consumed products made by the guild for the city's celebration of the feast day. ${ }^{92}$

The Bakers plausibly gifted their mayne bread to ingratiate themselves with civic authorities. Unfortunately the language used in their records is vague. Many times the 'bread' is simply documented as a Corpus Christi day expense: for example, 'Item payd ffor owre scheld xij d'. In 1547, however, the language is suggestive of a gift: 'Item for the shylde that we dyd gyve to my Lorde maier \& hys bredren of corpus crysti day $x[\mathrm{~d}] .^{93}$ The Bakers seem to have been on good terms with the corporation despite the fact that they were subject to surveillance and fines for violations of the Assize. When York revised its constitution in 1517, it created a common council advisory to the corporation; this council consisted of two members from each of thirteen major guilds and one member from each of fifteen minor guilds. The Bakers were included as one of the minor guilds while others were not made part of the council at all. ${ }^{94}$ According to Heather Swanson, crafts granted membership in the council were 'those most likely to be committed to the status quo'; 'In general the poor crafts lost any say they might have had in civic affairs, as did some of the large and potentially troublesome crafts such as tanners, cordwainers, smiths and carpenters. ${ }^{95}$ The Bakers' practice of gifting mayne bread to the corporation would have reminded the mayor and councillors of the Bakers' important part in local culture, as a craft skilled in the creation of a product closely tied to civic identity. Later evidence suggests that both those within and without the city regarded mayne bread as a unique cultural product, representative of York. When James I visited in 1617, he noted that mayne bread had not been offered to him: 'his Maiestie tolde the Lord Maior that he did mervaile that he had not sene maine bread and that he would not have it given over for that no other Cittye or Countrie made had or could make the like and did give 
the Lord Maior in Chardge that it should be mainteyned and vpholden'. ${ }^{96}$ Rice and Pappano have argued that in York 'artisans had a greater stake in local civic identity than merchants and laborers, mobile individuals who sometimes resided outside of the cities for extended periods of time. Artisan identity was tied to localism, and the cycle plays provided a key mechanism to produce and maintain that identity. ${ }^{97}$

Given the imprecise wording of the records, the Bakers possibly filled a yearly order for mayne bread placed by the mayor and council, in which case the city government flattered itself through comparison with Christ and his disciples. Lohman has argued that the York Mercers' play of the Last Judgement attempted 'to convince York's citizenry of the mercers' right to rule by comparing the ruling merchant class to the heavenly council of Christ and apostles'.98 In the Mercers' play, before the good and evil souls rise for judgement, Christ tells his apostles, ' 3 e schall sitte on seetis sere / Beside myselffe to se pat sight, / And for to deme folke ferre and nere / Aftir per werkyng, wronge or right. ${ }^{99}$ In Lohmann's reading, 'The scene mirrors the customs of York's civic governing bodies by depicting subjects who are called upon to account for their actions in front of both council and mayor, or in this case, the apostles and Christ'. ${ }^{100}$ By placing an order for mayne bread, the corporation perhaps attempted to enhance the comparison of the mayor and councillors to Christ and his apostles, a parallel intimated by the Mercers' final play of the cycle. Some evidence, however, suggests that the mayor and council only occasionally rewarded, rather than themselves orchestrated, the delivery of mayne bread on the feast day. In 1542, the City Chamberlains' books record a payment to the Bakers of $8 \mathrm{~d}$ for their 'present of sheyld of maynebrede' at Corpus Christi, ${ }^{101}$ which could suggest the 'bread' had been ordered; however, in the same year at Corpus Christi the mayor and council paid the Vintners the same amount 'for a great skallop of maynebrede ['made in the shape of a cockleshell'102] yat they haue been accustomed to gyf to my said lorde mayer $\&$ his brederne'. ${ }^{103}$ Similar records exist in other years: the Bakers' 1549 accounts note $8 \mathrm{~d}$ 'Ressawyd off the chamerlain ffor owre Scheld'; the City Chamberlains' books for 1554 record among other expenses for Corpus Christi day a 'Reward to the Bakers' and a 'Reward to the vynterners' of $8 \mathrm{~d}$ each, although the records do not specify that these payments are for mayne bread. ${ }^{104}$ Unfortunately there are no corresponding entries in the Bakers' account book for expenses in 1542 and 1554: the former records are missing and the latter documents make no reference at all that year to mayne bread. It seems unlikely that the mayor and council would have placed an order for molded biscuits with the Vintners; perhaps in these years 
only, as a special show of favour, the city recognized and reimbursed these two guilds for their longstanding, regular gifts on Corpus Christi day.

That the Bakers' and Vintners' guilds in particular customarily presented mayne bread to the mayor and council is significant given that both staged meals in their plays: the Last Supper and the Marriage at Cana. Unfortunately the latter text does not appear at all in the manuscript as the Vintners failed to register their pageant before the cycle and manuscript were retired. The two plays likely shared a special connection; as Beadle notes, the central miracle in the Vintners' play of Christ's transformation of water into wine 'was held to prefigure the institution of the eucharist, and in later medieval art the scene was usually pictured in such a way as to resemble the iconography of the Last Supper'. ${ }^{105}$ The Vintners' play — and possibly even the Bakers' play ${ }^{106}$ — could have featured the presence on the table or consumption of mayne bread since this 'bread' was associated with local celebrations and feasts: it was presented to Henry VII on his entry into the city in $1486,{ }^{107}$ was served at civic celebrations, ${ }^{108}$ and may have graced the tables of wealthy citizens at private events such as weddings. If mayne bread were present on stage at least in the Vintners' play, it would have functioned to link the depiction of the wedding feast at Cana to the many feasts taking place in York during the Corpus Christi celebration as well as with secular and religious feasts that occurred at other times during the year. ${ }^{109}$ And if the Vintners' pageant, as Beadle has suggested, visually mirrored the Bakers', wedding and other feasts in turn were compared or collapsed with the Last Supper, establishing connections between secular meals shared between spectators of the play and celebrations of the church sacrament.

This comparison need not have seemed problematic before the introduction of reforming theology to England or to traditionalists after, with the caveat again, if the play emphasized the Last Supper as the event depicted in the gospels. At every celebration of the mass, the words of the liturgy reminded celebrants and congregants of the sacrament's historical context, specifying its temporal point of origin 'Qui pridie quam patereture' [on the day before Christ was to suffer]. Before the consecration of the wine, the missal specifically described this event as sharing a meal: 'Simili modo posteaquam cenatum est ...' [In a similar manner, after having dined / eaten the meal]. That the mass was not identical to the historical event of the Last Supper was acknowledged, making possible representations drawing attention to their differences as well as similarities. ${ }^{110}$ Other medieval English visual representations of the Last Supper depicted the sacrament as a meal and the bread broken by Christ and shared with the disciples as ordinary loaves, not as wafers. For example, the Luttrell Psalter (East Anglia and/or Lincolnshire, 
1325-1340) shows Judas accepting into his mouth a crescent-shaped slice of bread from Christ's hand; on the table stand multiple round loaves, some with pieces missing that have presumably already been eaten. ${ }^{111}$ C.M. Kaufmann notes that this Last Supper can be compared with another image in the same manuscript of a family feasting; in the latter image, 'the table [is] covered in bowls and dishes, with more food being brought in by the servants, in contrast to the Last Supper, which has only bread and fish'. ${ }^{112}$ Both images, significantly, depict the bread identically, as loaves. In a fifteenth-century Hours of the Blessed Virgin Mary (London, 1420-30), slices of bread are arranged around the table; Christ again gives Judas a crescent shaped piece from his hand while two other apostles are depicted feeding themselves slices. ${ }^{113}$

Reformed theology similarly represented the Last Supper and Christ's Passion as events remembered in the celebration of the Lord's Supper and therefore temporally distant from the sacrament celebrated in churches. Reformers differed from conservatives and from one another in their interpretations of the elements after consecration - at one extreme, memorial symbolism or sacramentarianism (Zwinglianism) denied the corporeal presence of Christ's body in the bread and wine; Calvinism similarly denied the physical presence but recognized Christ's spiritual presence in the elements, while Lutheranism professed a union between the bread and wine and Christ's body and blood. Swiss Reformers (Zwinglians and Calvinists) also advocated a rejection of contemporary traditional ritual practice and a return (or attempt to return) to the sacrament's imagined original, simpler form: a shared meal and sacramental commensality. The souper of the Lorde (1533), previously believed by William Tyndale but now attributed to George Joye, ${ }^{114}$ advocated such a return with the adoption of a Zwinglian celebration of the sacrament in England; in this practice, ministers,

takynge the brede wyth grete reuerence, wyl deuyde it to the congregacyon euery man breking $\&$ rechyng it forthe to hys nexte neghbour and member of the mystik body of Cryst, other mynisters folowyng wythe the cuppis powering [pouring] forthe $\&$ dealynge them the wyne, all togyther thus beynge now partakers of one brede $\&$ one cuppe, the thynge therby sygnifyed $\&$ pryecheth prynted fast in their hertys. ${ }^{115}$

Conservatives who may not have objected to depictions of loaves of bread being shared in visual representations of the Last Supper certainly would have objected to their use in contemporary celebrations of the sacrament itself. A plaine and 
godlye treatise, concernynge the masse [and] the blessed sacrament of the aulter for the instruccion of the symple and vnlerned people (1555) decries 'sacramentaries' who

woulde make the worlde to wene that our sauiour Chryst, of his inestimable charitie shewed towarde vs in hys deathe and passion, had lefte vnto vs in the blessed Sacramente but a bare peece of bakers breade, as a sygne of hys bodye (whiche in very dede were but a symple and a poore meane memoriall of so greate charitie) and not hys very bodye in deede. ${ }^{116}$

While 'bakers breade' signifies the untransubstantiated element, it also conjures to mind a particular type or shape of bread.

Given the close association drawn between bakers' bread and 'sacramentaries', the York Bakers' pageant may have allowed readings of the moment it dramatized ranging from traditionally transubstantive to reformed memorialist. Conservatives would have recognized the event within its original context, as would reformers, who may also have seen in the historical celebration of the Lord's Supper a model for contemporary imitation. The choice to return to the sacrament's moment of origin would have allowed multiple understandings of the ritual it inaugurated, perhaps explaining the play's continued performance through a period of religious instability. Jay Zysk has argued that Christ's words of institution recorded in the gospel narratives ('This is my body', 'This is my blood'), because they do not specify how they should be interpreted, functioned during the Reformation as a 'semiotic interruption';117 debates centred on whether the verb 'is' here could and should be read to some degree or exclusively as 'signifies'. ${ }^{118}$ By representing that moment of 'semiotic interruption' more than its subsequent interpretation, the Bakers' pageant could have accommodated multiple religious perspectives. The play then would have exhibited an 'openness to alignment with conflicting religious and doctrinal positions' similar to that noticed in the Chester cycle of plays by Theresa Coletti, who credits this openness with the cycle's continued performance through the mid-to-late sixteenth century. ${ }^{119}$

As accommodating as this staging choice would have been, the Bakers' representation of the bread as a loaf or loaves would in some respects have affected its potentially diverse audience members similarly, calling to mind contexts other than the ecclesiastical and liturgical. Lee Palmer Wandel, analyzing a pair of woodcuts depicting the Last Supper printed on the title pages of two of Zwingli's works on the mass, ${ }^{120}$ notes the absence in these images of components commonly seen in traditional depictions of the event: 'Gone is the carefully molded eucharist wafer, whose size, shape, and composition were carefully regulated. 
Gone are the ornate monstrances and patens of late medieval liturgy. Gone is the elevation of the host and its invocation of the crucifixion. And gone are the elaborate, formalized rituals and the distance they enacted between the laity and the eucharist.' ${ }^{121}$ Less common representations present in the woodcuts convey very different associations and meanings than would those they replace. Wandel singles out for analysis the images' representation of bread:

the bread in the woodcuts looks like the loaves baked for any household's consumption. These loaves are not the strictly regulated, carefully contrived wafers, which had to be consecrated by a priest, but the everyday food of the laity. They are mundane, common; this bread can be found in any household. In substituting bread for the wafer, these images reintroduce into conceptualizations of the Last Supper an object found commonly in lay households; they reintroduce the mundane into the religious. ${ }^{122}$

The particular representation of bread here and potentially in the York Bakers' pageant established a clear connection between meals eaten by spectators in their homes every day, the historical Last Supper, and celebrations of the sacrament, traditional or reformed. The Bakers, by depicting the bread as a loaf and therefore as a product of their particular craft and skill, furthermore used their pageant to assert their importance in biblical history and in the contemporary civic social structure. Rice and Pappano suggest that the cycles allowed 'artisans to sanctify their work and to represent themselves and craftwork as central to their city's devotional life. ${ }^{123}$ Few crafts could claim a more central place in day-to-day civic life than the Bakers, who produced arguably the most important food staple in York as well as the original 'stuff' (or symbol) of Christ's body.

To conclude, I return to this paper's original problem: when and why might the leaf from quire R have been removed from the York register? Extant records point to religious and political intervention in civic theatrical performances in York late in their histories, intervention seen also in other northern communities. In late March 1568, Matthew Hutton, dean of York Minster, effectively halted production of one of the city's other major theatrical productions, its Creed play, after examining the text and warning the council, 'see I manie thinges, that I can not allowe, because they be Disagreinge from the senceritie of the gospell'. ${ }^{124}$ The same year on 27 April, council members discussed producing the Corpus Christi plays instead; however, they decided that 'the book thereof shuld be perused / and otherwaise amendyd / before it were playd'. ${ }^{25}$ The Corpus Christi plays' last recorded production was the following year at Whitsun, 
a clear concession to reformers. And in 1572, the final performance of the city's other major theatrical production, the 'Pater Noster' play, took place, causing 'a major dispute in the York City Council that led to the imprisonment and disenfranchisement of two aldermen'. ${ }^{126}$ The same year, Archbishop of York Edmund Grindal wrote to the mayor of Chester ordering him to halt the city's production of its Whitsun plays 'this Summer \& for all times hereafter till your said plays shall be perused corrected \& reformed by such learned men as by us shall be thereunto appointed $\&$ the same so reformed by us allowed' ${ }^{127}$ In 1576 , the Wakefield play was suppressed by order of the Ecclesiastical Commission. ${ }^{128}$ And in April 1579, a very likely spooked York city council considered submitting the register to the new Archbishop of York Edwin Sandys and (still) Dean of York Minster Matthew Hutton for review and, if necessary, correction before any future performance. ${ }^{129}$

Eileen White has cautioned that, despite their resolution to have the manuscript examined and revised, the mayor and council of York may have thought better and kept the register close, as 'there is no confirmation that the order had been followed through' ${ }^{130}$ Clifford Davidson has suggested that civic authorities probably did submit the manuscript for review and that before doing so they may themselves have removed the missing leaf from 'The Last Supper', perhaps hoping to avoid the dean and archbishop's disapproval of the cycle of plays as a whole. ${ }^{131}$ If this were the case, however, it seems strange that city authorities left the Mary pageants in the manuscript since they recognized early on that these plays were problematic and removed them from productions of the cycle. The dean and archbishop likely removed the leaf after reviewing the manuscript if they did - and before returning it to the corporation — again, if they did. The register disappears from civic records and re-emerges in documentation of a private manuscript collection at the end of the seventeenth century. ${ }^{132}$ No subsequent performance of the Corpus Christi plays is recorded although in April 1580 the citizens of York requested they be produced again that year. ${ }^{133}$

At some point in this history, someone removed the leaf — but on evidence of the records, likely not because the play depicted the Last Supper as a problematic conservative and traditional celebration of the mass. In 1576, Matthew Hutton, dean of York Minster, famously decreed that 'no Pageant be vsed or set furthe wherein the Maiestye of god the father god the sonne or god the holie ghoste or the administration of either the sacramentes of Baptisme or of the lordes Supper be counterfeyted or represented'. ${ }^{134}$ Perhaps in response to this injunction some authority took a knife to the register, unconcerned how the institution of the sacrament was represented in the cycle, concerned only that at one specific point in 
the manuscript it was. Pamela King has suggested that the leaf's removal as well as modern literary historians' interest in that removal reveal a common fundamental misunderstanding of the play: 'in focusing on this pageant for instruction on the Sacrament of the Altar we may be making the same mistake as the owner of the hand that removed the leaf: because the whole cycle was designed to embellish the Feast of Corpus Christi, the impact of the Sacrament of the Altar is not restricted to a single pageant but is threaded through the whole cycle'. ${ }^{135}$ The manuscript's vandal, alternatively, may have known exactly what he was doing. If the Bakers' play was in fact considered central to the York Corpus Christi cycle, by removing the leaf he cut out its metaphoric heart. Whoever censored the play possibly intended to censor the cycle as a whole and prevent its future production. That action symbolically deactivated a practice and cultural artefact perhaps two hundred years old. 


\section{Notes}

I would like to thank Dr Almute Grohmann-Sinz for generously sharing her research with me.

1 See Richard Beadle, 'Nicholas Lancaster, Richard of Gloucester and the York Corpus Christi Play', in The York Mystery Plays: Performance in the City, ed. Margaret Rogerson (Woodbridge, 2011), 31-52, especially 48-52.

2 Richard Beadle has suggested that Richard of Gloucester's interest in the plays and membership in the York Corpus Christi guild may in part have inspired the manuscript's compilation beginning in 1476 (ibid), while Clifford Davidson has noted that the register was compiled in a decade (the 1570s) 'noted across England for unusually virulent epidemics'; 'One may speculate that in a time of population fluctuation the corporation may have decided to collect playscripts that it felt otherwise might be lost'. See Clifford Davidson, 'York Guilds and the Corpus Christi Plays: Unwilling Participants?', Early Theatre 9.2 (2006), 24, https://doi.org/10.12745/et.9.2.727.

3 Richard Beadle, ed., The York Plays: A Critical Edition of the York Corpus Christi Play as recorded in British Library Additional MS 35290, 2 vols (Oxford, 2009, 2013 for 2011), 1.xxi-xxii.

4 One accidental loss, of a singleton added in quire $\mathrm{G}$ in the Chandlers' 'Annunciation to the Shepherds', likely contained an angel's appearance announcing Christ's birth. Another, of a vulnerable innermost bifolium of quire B (containing half the action of 'Cain and Abel'), may have been accidental or intentional; John Clerke, the York common clerk from $1538 / 39$ to 1580 , noticed the missing biofolium and attempted, as Beadle notes, either 'to rectify an accidental loss, or possibly to substitute for material deliberately removed' from the manuscript. See Beadle, York Plays, 1.xxivxxv. As the first editor of the plays, Lucy Toulmin Smith, observed, 'In five of the quires ... a pair of leaves has been removed, it would almost seem purposely, for the volume is not in such a loose condition that they could have fallen out'. See Smith, York Plays: The Plays Performed by the Crafts or Mysteries of York on the Day of Corpus Christi in the 14th $15^{\text {th }}$, and $16^{\text {th }}$ Centuries (London, 1885; New York, 1963), xiv. One apparently intentional removal, of the innermost blank bifolium of quire G, did not carry away text. Other likely intentional excisions did: from quire $\mathrm{O}$ (removing sections of 'The Woman Taken in Adultery'), from quire R (removing sections from 'The Last Supper' and 'The Agony in the Garden and Betrayal'), and from quire \& (removing sections from 'Christ before Pilate II' and 'The Road to Calvary').

5 Beadle, The York Plays, 1.xxv. 
6 For reform campaigns in the north, particularly as they related to the religious drama, see Alexandra F. Johnston, "And how the state will beare with it, I knowe not", Medieval English Theatre 30 (2008), 3-25; and Elizabeth Baldwin, "'Obedience is good, but ...": Christopher Goodman, the Chester Plays, and the Problem of Authority', Yearbook of English Studies 43 (2013), 281-98, https://doi.org/10.5699/ yearenglstud.43.2013.0281.

7 Richard Beadle, The York Plays (London, 1982), 231.

8 Beadle, The York Plays (Oxford, 2009, 2013 for 2011), 2.224. All subsequent references to Beadle will be to this most recent edition.

9 Clifford Davidson, The York Corpus Christi Plays, TEAMS Middle English Texts Series (Kalamazoo, 2011), 447.

10 Clifford Davidson, From Creation to Doom: The York Cycle of Mystery Plays (New York, 1984), 91. In a later article, Davidson emphasizes the importance of the play while he is more neutral about its possible staging: the loss of the leaf, he writes, is 'an unfortunate occurrence since representation of the consecration of communion bread and wine, however it was done, would have been critical'; Clifford Davidson, 'Memory and Remembering: Sacred History and the York Plays', in ed. Petter Happé and Wim Huskin, Staging Scripture: Biblical Drama 1350-1600 (Leiden, 2016), 348.

11 Rice and Pappano attempt to explain yearly payments recorded in the Bakers' accounts of ten shillings, eight pence 'to the plaer ffor playng off the pagand'. They suggest that this 'large sum', if 'remuneration to a single actor', would likely have been paid to the actor of the central role. If a priest performed the role, Rice and Pappano assume the pageant's depiction of the Last Supper would incorporate liturgical actions intended to evoke traditional celebrations of the mass. This casting choice could be problematic, however: even as simulation, if the priest spoke the words of consecration over wafers or bread, would he effect transubstantiation? As Rice and Pappano acknowledge in a footnote, Beadle 'conjectures that the payment was to a "particular individual" who acted as "the producer of the pageant" and who may also have directed and/or acted' and not to an individual player, whether or not a priest. See Beadle, York Plays, 2:222; Nicole R. Rice and Margaret Aziza Pappano, The Civic Cycles: Artisan Drama and Identity in Premodern England (Notre Dame, 2015), 25, 25 n 120.

12 Brian Cummings, ed., The Book of Common Prayer: The Texts of 1549, 1559, and 1662 (Oxford, 2011), 27.

13 John Roche Dasent, ed., Acts of the Privy Council of England Volume 3, 1550-1552 (London, 1891), 228. British History Online, http://www.british-history.ac.uk/actsprivy-council/vol3. 
14 Alexandra Walsham, 'Recycling the Sacred: Material Culture and Cultural Memory after the English Reformation', Church History 86.4 (2017), 1127, https://doi. org/10.1017/S0009640717002074. See also Charles Oman's discussion of the Edwardian inventories and confiscation of church goods in English Church Plate, 5971830 (London, 1957), 121-6.

15 Claire Cross, 'Endings and Beginnings', in Mass and Parish in Late Medieval England: The Use of York, ed. P.S. Barnwell, Claire Cross, and Ann Rycraft (Reading, 2005), 116.

16 Oman, English Church Plate, 126.

17 Ibid, 133.

18 Ibid. According to Oman, the hallmark date is significant: 'the first landmark for us is the restoration of the cup to the laity by proclamation on 22 March [1558/9], Wednesday in Holy Week. Since only eight weeks of the hall-marking year remained to run, it is really remarkable that we should still retain a communion cup marked during this short period' (133).

19 Ibid, 126.

20 Iniunctions Giuen by the Most Reuerende Father in Christ, Edmonde by the prouidence of God, Archbishop of Yorke (London, 1571; sTC 10375), A2v, Early English Books Online (EEBO).

21 Cummings, The Book of Common Prayer, 140.

22 'It is ordered for the more reuerence to be geuen to these holy misteries, being the sacramentes of the bodye and bloud of our Sauior Jesus Chryst, that the same sacramentall bread be made and formed plaine without any figures therupon, of the same finenesse $\&$ fashion rounde, though somwhat bygger in compasse and thickenes, as the usuall breade and wafer heretofore named syngynge cakes, which serued for the use of the priuate masse'. 'For the Tables in the Church', Iniunctions geuen by the Quenes Maiestie (London, 1559; sтс 10099.5), image 16, ЕЕво. Quoted in modern spelling in Maggie Bullett, 'The Reception of the Elizabethan Religious Settlement in Three Yorkshire Parishes, 1559-72', Northern History 48.2 (2011), 251, https://doi. org/10.1179/007817211X13061632130485.

23 For a comprehensive discussion of the decades following the 1559 Prayer Book and royal injunctions, see Christopher Haigh, "AA Matter of Much Contention in the Realm”: Parish Controversies over Communion Bread in Post-Reformation England', History 88.3 (2003), 393-404, https://www.doi.org/10.1111/1468-229X.00269.

24 James F. Turrell, 'Anglican Liturgical Practices', in A Companion to the Eucharist in the Reformation, ed. Lee Palmer Wandel (Leiden, 2014), 280. In 1569, the conservative Bishop of Chester William Downham and the reformed preacher Thomas Goodman clashed over a number of points of practice in the latter's parish church, 
including Goodman's use of 'common bread' instead of wafers for communion (Baldwin, “'Obedience is good, but ...”, 287-9). In 1571, in the Yorkshire parish of Masham, conflict broke out between the new parish vicar Anthony Ford and two of his parishioners at the dismantling of the rood loft and burning of the crucifix. One of the parishioners who objected to the burning of the image, Leonard Atkynson, was accused additionally of possessing 'yrons for printed caks'. Maggie Bullett concludes, 'Atkynson was therefore involved with the making of Eucharistic wafers with crosses on them, evidence that the Mass had been continuing until very recently within the parish church, and was now probably continuing elsewhere' ('The Reception of the Elizabethan Religious Settlement', 242).

25 British Library Add MS 33852.

26 Alexandra F. Johnston and Margaret Rogerson (eds), REED: York, 2 vols (Toronto, 1979), 1.291, 1.39-292, 1.2; 1.331, 1.41-332, 1.2; 1.310, 1l 18-20; Beadle York Plays, 2.xxxiv.

27 Johnston and Rogerson, eds, REED: York, 1.298, 11 18-37; see Davidson, The York Corpus Christi Plays, 12.

28 Johnston and Rogerson, eds, REED: York, 1.327, 11 13-14.

29 Yearly performances were suspended in 1565 when flooding destroyed Ouse Bridge, 'effectively cutting the city in half' until its reconstruction late in 1566. Alexandra Johnston, 'The City as Patron: York', in Shakespeare and Theatrical Patronage in Early Modern England, ed. Paul Whitfield White and Suzanne R. Westfall (Cambridge, 2002), 167-8.

30 Johnston and Rogerson, eds, REED: York, 1.315, 11 3-6, 11-13.

31 Johnston, 'The City as Patron', 165.

32 See Paul Whitfield White, Drama and Religion in English Provincial Society, 14851660 (Cambridge, 2008), 66-101, especially 72-4 (which outline revision in the Coventry cycle), 79-88 (which outline revision of the Norwich Grocers' Pageant), and 89-97 (which outline revision of the Chester cycle).

33 Norman Jones, The English Reformation: Religion and Cultural Adaptation (Oxford, 2002), 9.

34 Ibid, 2.

35 A.G. Dickens, Lollards and Protestants in the Diocese of York 1509-1558 (London, 1959).

36 Ethan H. Shagan, Popular Politics and the English Reformation (Cambridge, 2003), 306.

37 Pamela M. King has argued that the day of performance was centrally important. See 'The York Plays and the Feast of Corpus Christi: a Reconsideration', Medieval English Theatre 22 (2000), 14. 
38 Paul Whitfield White, Drama and Religion, 90. Elizabeth Baldwin, Lawrence M. Clopper, and David Mills suggest further that within the Shoemaker's larger revised play 'The Last Supper was represented perhaps in a shortened or Protestantsanctioned form'. See Baldwin, Clopper, and Mills (eds), REED: Cheshire Including Chester, 2 vols (Toronto, 2007), 2.893.

39 Whitfield White, Drama and Religion, 90.

40 Baldwin, Clopper, and Mills, eds, REED: Cheshire, 1.338, $113-5$; 11 3-4 qtd in Whitfield White, Drama and Religion, 90.

41 Erin E. Kelly, 'Doubt and Religious Drama Across Sixteenth-Century England, or Did the Middle Ages Believe in Their Plays?', in The Chester Cycle in Context, 15551575: Religion, Drama, and the Impact of Change, ed. Jessica Dell, David Klausner, and Helen Ostovich (Surrey, 2012), 48.

42 Theodore Lerud, 'Negotiating the Reformation in the Northwest: The Reinvention of the Chester Cycle', Reformation 8.1 (2003), 1-39, https://doi.org/10.1179/ ref_2003_8_1_002.

43 Beadle, York Plays, 2.227, n 89+. Lucy Toulmin Smith estimates that the missing section contained 'about 65' lines (her York Plays, 236).

44 Beadle, York Plays, 2.224. Pamela King writes of the missing section, 'whatever took place must have been economical and straightforward'. The York Mystery Cycle and the Worship of the City (Cambridge, 2006), 174.

45 For a discussion of the N-Town representation, see Theresa Coletti, 'Sacrament and Sacrifice in the N-Town Passion', Mediaevalia 7 (1981), 239-64.

46 Stephen Spector, ed., The N-Town Play, Cotton MS Vespasian D.8, Early English Text Society (EETs) (Oxford, 1991), Play 27, 1. 273, 1. 257.

47 Ibid, 1. 281, 1. 451.

48 R.M. Lumiansky and David Mills, eds, The Chester Mystery Cycle, EeTs (London, 1974, 1986), 3, 9, Play 15, 1.272, 1.88 sd.

49 Ibid, 1.272, $1.104 \mathrm{sd}$.

50 Ibid, 1.273, 1l 121-2; 1. 273, 1. $120 \mathrm{sd}$.

51 Beadle, York Plays, Play 27, 1. 224, 1. 20. This divisible roast lamb appears as a stage property in the Bakers' pageant expenses, which periodically record costs for 'mendeng the lam' (Johnston and Rogerson, eds, REED: York, 1.309, 1. 22; see also $1.325,1.10)$.

52 Beadle, York Plays, Play 27, 1. 225, 1.31.

53 Ibid, 2. 227, n 89+.

54 Ibid, Play 27, 1. 226, 11 90-1.

55 Lumiansky and Mills, eds, The Chester Mystery Cycle, Play 15, 1. 274, 1. 133.

56 Spector, The N-Town Play, Play 27, 1. 281, 1. 465. 
57 For example, in Arnoul Greban's Le Mystère de la Passion, a piece of ordinary 'pain bis' (brown bread) is specifically called for to represent the bread Judas dips in Christ's dish. Muir erroneously suggests, however, that N-Town conflates the host with the sop, perhaps having missed the earlier incident before Judas's first exit. See Lynette Muir, 'The Mass on the Medieval Stage', Comparative Drama 23 (1989/90), 323, https://doi.org/10.1353/cdr.1989.0034.

58 P.T. Durbin and Lynette Muir, eds, The Passion de Semur (Leeds, 1981), 169, 1.5962 sd and 171, 1. 6042 sd; Muir, 'The Mass', 323. The representation in Semur perhaps evokes the act of intinction, the dipping of a eucharistic wafer in wine by the priest to soften it, intended to assist the very sick or very young who otherwise would have difficulty swallowing the host. See W.E. Scudamore, Notitia Eucharistica, a Commentary, Explanatory, Doctrinal, and Historical, on the Order for the Administration of the Lord's Supper or Holy Communion (London, 1876), 705-7. Intinction as a practice was repeatedly condemned and was only allowed and/or survived in isolated geographical pockets after the 1415 Council of Constance, which affirmed concomittance and finally made law the long custom of communicating under one kind. Arguments against intinction noted that the practice was reminiscent of Judas's act of dipping his bread into the sop or receiving intincted bread from Christ's hands at the Last Supper and was therefore not appropriate for the communion of the faithful. See John M. Huels, 'The Interpretation of the Law on Communion under Both Kinds', PhD thesis (Catholic University of America, 1982), 117-18, $107-8,80-2$.

59 Johnston and Rogerson, eds, REED: York, 1.285, 1.5. See also 1.309, 1.22 and 1.358, 1.15

60 Anna Mill, 'The York Bakers' Play of the Last Supper', The Modern Language Review 30.2 (1935), 152, https://doi.org/10.2307/3716093.

61 Richard Beadle suggests that the play in its current form is even older based on the unusual order of the events it dramatizes (Christ's washing of the disciples' feet precedes his institution of the Last Supper) and evidence in the records that it was once two separate plays that later were combined: 'it ... seems probable that the surviving Bakers' pageant is a revision dating from Roger Burton's time'. Roger Burton was common clerk from 1415 to 1435. York Plays, 2.221.

62 Wastel, simnel, payndemayne/demesne, and cocket were types of bread distinguished by the quality of flour used in each. For the types of bread produced by the Bakers' guild in York, see Ann Rycraft, 'Can We Tell What People Ate in Late Medieval York?', in Feeding a City: York, ed. Eileen White (Totnes, 2000), 61-78 (especially 63-4); and Peter Brears, 'The Food Guilds of York', Feeding a City: York, ed. Eileen White 79-100 (especially 86-7). 
63 Brears, 'The Food Guilds of York', 90.

64 Oed Online, s.v. 'wafer'.

65 Peter Hammond, Food \& Feast in Medieval England (Phoenix Mill, 1993, 2005), 112. For example, John Russell's Boke of Nurture, 'a complete Manual for the Valet, Butler, Footman, Carver, Taster, Dinner-arranger, Hippocras-maker, Usher and Marshal of the Nobleman of the time when the work was written, the middle of the fifteenth century' (cix), recommends the service of 'Waffurs to ete / ypocras to drynk' as part of the third course of a dinner of flesh $(166,11715)$, the fourth course of a dinner of fish $(168,1.759)$, and the end of a feast for a franklin $(171,1.816)$. Wynkyn de Worde's Boke of Keruynge (second edn, 1513), based on Russell's Boke of Nurture or working with an original common to both texts (cxi), makes similar recommendations $(271,280)$. Both texts are published in Frederick J. Furnivall, ed., Manners and Meals in Olden Time: The Babees Book and The Bokes of Nurture, EETs (London, 1868; New York, 1969). For a discussion of waferers employed by noble houses, see Richard Rastall, 'The Waferers', in 'Secular Musicians in Late Medieval England', PhD thesis (Victoria University, 1968), 187-90.

66 Better documentation survives from France, where after 1270 members of a newly created guild in Paris, the Oblayeurs, produced wafers for the church as well as secular wafers for sale to members of the public. See Janny de Moor, 'The Wafer and Its Roots', in Look and Feel: Studies in Texture, Appearance and Incidental Characteristics of Food, ed. Harlan Walker (Oxford, 1994), 120-1.

67 See William Langland, Piers Plowman, Passus 7: “Wyte god”, quod a wafrestere [female waferer], "wiste y this for sothe, / Wolde y neuere forther no foet for no frere prechynge!"' Derek Persall, ed., Piers Plowman by William Langland: An Edition of the C-text (London, 1978), 144, 11 285-6. See also Geoffrey Chaucer, 'The Pardoner's Tale': 'And right anon thanne comen tombesteres / Fetys and smale, and yonge frutesteres, / Syngeres with harpes, baudes, wafereres, / Whiche been the verray develes officeres / To kyndle and blowe the fyr of lecherye, / That is annexed unto glotonye'. Geoffrey Chaucer, 'The Pardoner's Tale', The Canterbury Tales, ed. Larry D. Benson in The Riverside Chaucer, third edn (Boston, 1987), 196, 1l 477-82.

68 Erika T. Lin, 'Popular Festivity and the Early Modern Stage: The Case of George a Greene', Theatre Journal 61.2 (2009), 279, https://doi.org/10.1353/tj.0.0184. Waferers received gratuities from York on various dates alongside travelling players, musicians, minstrels, a jester, and a fool in 1446, 1447, and 1448. See Johnston and Rogerson, eds, REED: York, 1.65-8, 69-70, and 71-3. Johnston and Rogerson in their note to the 1446 list of gratuities write, 'The only meaning given for 'waferer' in the oed is "a maker or seller of wafers or thin cakes". The constant appearance of 
these men in these lists suggests, perhaps, that the word may also have the force of "wayfarer" or "vagabond"' (2.871, $\mathrm{n}$ for 65$)$.

69 Henry Philibert Feasey, 'A Pair of Wafer-Irons', The Antiquary 35 (1899), 49-51.

70 Cambridge University Library MS LI 2.2; Miri Rubin, Corpus Christi: The Eucharist in Late Medieval Culture (Cambridge, 1991), 42-3.

71 Stephen Morrison, ed., A Late Fifteenth-Century Dominical Sermon Cycle, eets (Oxford, 2012 for 2011), 1. 185, 11 214-17. John Mirk recounts the same tale, identifying the woman as 'Lasyna'. Mirk's text does not explain Lasyna's motivation for or participation in the making of wafers for the mass; he seems to assume that the situation would be a familiar one to English readers. Susan Powell, ed., John Mirk's Festial, eets (Oxford, 2009, 2011), 1. 159, 11 164-84.

72 Raine, Fabric Rolls of York Minster, 124, 127, 136.

73 Edward Peacock, 'Inventory of a Trader, a.d. 1519', Gentleman's Magazine 216 (1864), 501-2.

74 Food historian Ann Rycroft notes that bakers made comparable items - 'the rusklike byskettes which were bought for the Corpus Christi feast in 1554' - but 'probably not the wafers which snowed in a pageant presented at Henry VII's entry in 1486, which were probably not baked, but made on wafering irons'. See Rycraft, 'Can We Tell What People Ate', 64. For a description of the 'casting oute of obles \& Wafers' on this occasion see Johnston and Rogerson, eds, REED: York, 1.149, 11 33-7. Biscuits and bread showcased different skill sets than did wafers as well as different levels of access to food production technologies - rarer ovens compared to more common, if not ubiquitous, household hearth fires.

75 Tony Corbett, The Laity, the Church and the Mystery Plays: A Drama of Belonging (Dublin, 2009), 62.

76 Sarah Beckwith, Signifying God: Social Relation and Symbolic Act in the York Corpus Christi Plays (Chicago, 2001), 53.

77 Rice and Pappano, The Civic Cycles, 5.

78 Johnston and Rogerson, (eds), REED: York, 1.294, 1.26; see also the year 1557, 1.325, $1.32-3$, which records a payment to minstrels 'yat day yat we mayd owre mandy bred'.

79 Ibid, 'mande bred', 2.919.

80 In 1585, members of the guild who 'cam not to manndye breade makinge' were fined, while from 1594 to 1599 , fines collected by the guild's searchers were directed to the yearly cost of making 'mawnde bread'. Ibid, 1. 425, 11 37-9; 1. 460, 1l 35-6; 1. 465, 1l 31-2; 1. 471, 1. 42-472, 1. 1; 1. 477, 1. 22; 1. 483, 11 27-8; 1. 489, 11 6-7.

81 Eamon Duffy, The Stripping of the Altars: Traditional Religion in England c.1400c.1580 (New Haven, 1992), 125. The Stanford Churchwardens' accounts for 
1552-1602 explain the process in some detail. See Walter Haines, 'Stanford Churchwardens' Accounts (1552-1602)', The Antiquary 17 (1888), 71.

82 Ironically, after the Reformation a loaf of bread would have seemed much more the purview of that institution. The sharing of holy bread after mass was abolished first by the 1549 Book of Common Prayer - see Cummings, Book of Common Prayer, 39 and Duffy, Stripping of the Altars. Duffy explains, 'In a series of instructions at the end of the Communion service, the prayer-book ordered that the old holy loaf rota should now become a rota for households in the parish to pay the communion expenses, and that "some one at the least of that house in every Parishe", or at least a deputy appointed by them, should receive with the priest' (464). Communion bread differed significantly from holy bread and did not carry the same meaning beyond the walls of the church.

83 Meisha Lohmann, “'On the Pavement, Thinking About the Government”: The Corpus Christi Cycle and the Emergence of Municipal Merchant Power in York', Mediaevalia 32 (2011), 124.

84 Ibid, 123.

85 For Lohman's discussion of this guild and its play, see ibid, 130-7.

86 Heather Swanson, Medieval Artisans: An Urban Class in Late Medieval England (Oxford, 1989), 12. For a discussion of legislation concerning the Bakers and other food and drink guilds, see chapter 2, 'The Victualling Industry', 9-25 and chapter 9, 'Artisans and the Civic Authorities', 107-26.

87 P.M. Tillott, ed., A History of Yorkshire: The City of York, The Victoria History of the Counties of England (London, 1961), 99; Swanson, Medieval Artisans, 12.

88 'The York Bakers' Play', 153.

89 'Die Sonderstellung des schwäbischen Springerle und sein Bezug zu einem mittelalterlichen Gebäck aus England', Neue Beiträge zur Modelbackkunst (self published, 2013), copy supplied by the author without original pagination; see also, 'Historic “Mayne” Bread Recipe Recreated', The Press (12 February 2013), http://www.yorkpress.co.uk/news/10221360. Historic mayne bread recipe recreated/.

90 oEd Online, s.v. 'shield'.

91 Jesse Njus, 'Look Who's For Dinner: Staging the Last Supper in Medieval Drama', in Food and Theatre on the World Stage, ed. Dorothy Chansky and Ann Folino White (New York, 2015), 156-7.

92 The Bakers did provide a shield of mayne bread to the council for other theatrical productions. An expense is noted for 1545, a year in which the Creed play was performed instead of the Corpus Christi plays, and in 1572, a year in which 'The Pater Noster' was produced. See Johnston and Rogerson, eds, REED: York, 1.286, 1. 34; $1.372,11$ 13-14. For a discussion of these two plays, their forms, and what they 
perhaps dramatized, see Alexandra F. Johnston, 'The Plays of the Religious Guilds of York: The Creed Play and the Pater Noster Play', Speculum 50.1 (1975), 55-90, https://doi.org/10.2307/2856513. Johnston notes that the Bakers' records for 1572 make clear that 'their pageant of the Last Supper and its gear were part of the performance' of the Pater Noster play (73), likely illustrating the Lord's Prayer request 'Give us this day our daily bread' (77). Thus, the Bakers' presentation of mayne bread would signify similarly at this production.

93 Johnston and Rogerson, eds, REED: York, 1.286, 1.34 and 1.291, 11 30-1. That the shield was of mayne bread is specified in other records, for example in the 1572 record noted above: 'Item for a Sheyld of maynbread to carry to my Lord Mayour xij d' (1.372 11 13-14).

94 Swanson, Medieval Artisans, 123.

95 Ibid, 124.

96 Johnston and Rogerson, eds, REED: York, 1.556, 11 15-20.

97 Rice and Pappano, The Civic Cycles, 33.

98 Lohman, “'On the Pavement”, 138.

99 Beadle, York Plays, Play 47, 1.447, 11.189-92.

100 Lohman, “'On the Pavement"', 138.

101 Johnston and Rogerson, eds, REED: York, 1.280, 11 41-2.

102 Ibid, 2.920.

103 Ibid, 1.280, 11 36-9.

104 Ibid, 1.294, 1. 2; 1.316, 11 39-40.

105 Beadle, York Plays, 2.181.

106 C.M. Kauffmann has noted that in some visual representations of the Last Supper 'the table contains popular local foods' - for example, crayfish in the Alpine region north of Venice; C.M. Kauffmann, Eve's Apple to The Last Supper: Picturing Food in the Bible (Woodbridge, 2017), 139.

107 Johnston and Rogerson, eds, REED: York, 1.137, 11 38-40.

108 For example, on the Friday after Corpus Christi day in 1554 along with biscuits, apples, and wine - see Johnston and Rogerson, eds, REED: York, 1.317, 1l 17-19; on the election day of the lord mayor with beer or ale and wine (ibid, 1.326, 11 32-3); and on midsummer's evening from 1584 for the mayor, aldermen, and ladies at the midsummer play (ibid, 1.411, 1. 4 and 420, 1. 28).

109 For a similar analysis of the function of feasting in the Chester cycle plays, see Matthew Sergi, 'Staging Festive Piety: Staging Food and Drink at Chester', Medieval English Theatre 31 (2009), 89-136. Sergi argues the plays 'establish continuity between Cestrian urban revelry and the teachings, tradition, and ritual of Church feasts by rendering the latter in the localized, familiar terms of the former: as the 
structure of the secular celebration is legitimised, religion's fundamental and central place in that structure is secured' (92).

110 Lee Palmer Wandel makes a similar point as he analyzes two reformed woodcuts representing the Last Supper; see Lee Palmer Wandel, 'Envisioning God: Image and Liturgy in Reformation Zurich', Sixteenth Century Journal 24.1 (1993), 36, https:// doi.org/10.2307/2541794.

111 British Library Add MS 42130, f. 90v; http://www.bl.uk/manuscripts/Viewer. aspx?ref=add_ms_42130_f090v.

112 Kauffmann, Eve's Apple, 135. For the image, see British Library Add MS 42130, f 208r; http://www.bl.uk/manuscripts/Viewer.aspx?ref=add ms 42130 f208r.

113 British Library Add MS 50001, f. 7r; http://www.bl.uk/manuscripts/Viewer. aspx?ref=add ms $50001 \mathrm{f} 007 \mathrm{r}$.

114 See Orlaith O'Sullivan, 'The Authorship of The Supper of the Lord', Reformation 2.1 (1997), 207-38, https://doi.org/10.1179/ref 199721010 . The text was considered sufficiently threatening that Thomas More himself refuted it the following year in his Answere to the Fyrst Parte of the Poysened Booke, which a namelesse heretyke hath named the souper of the lorde (London, 1534). Joye's text was printed repeatedly during the reigns of Henry VIII and Edward VI. See W.D.J. Cargill Thompson, 'Who Wrote "The Supper of the Lord?"', Harvard Theological Review 53.1 (1960), 77, https://doi.org/10.1017/S0017816000026894.

115 The Souper of the Lorde Wher vnto, that thou mayst be the better prepared and suerlyer enstructed (Antwerp or London, 1533; sтC: 24468), fol 32r / D8r), ЕEво.

116 A Plaine and Godlye Treatise, concernynge the masse [and] the blessed sacrament of the aulter for the instruccion of the symple and vnlerned people (London, 1555; sTC: 17629), B1r, EЕво. The reference to 'bakers bread' here assumes that bread produced by the Bakers guild was very different from the hosts used in traditional celebrations of the eucharist, further evidence that the guild was likely not involved in the production of wafers.

117 Jay Zysk, Shadow and Substance: Eucharistic Controversy and English Drama Across the Reformation Divide (Notre Dame, 2017), 26.

118 See, for example, Joye, Souper of the Lorde: 'So that this maner of speche in thadministracion \& vse of the souper of our lorde: to saye This is my bodye, and this is my bloode: is as miche to saye as, This signifyeth my body, thys sygnifyethe my bloode, whiche souper is here celebrated to put vs in rememberance of Cristes dethe, and to excyte vs to thankis geuinge' (fol $19 \mathrm{r}-\mathrm{v} / \mathrm{C} 3 \mathrm{r}-\mathrm{v}$ ) .

119 Theresa Coletti, 'The Chester Cycle in Sixteenth-century Religious Culture', Journal of Medieval and Early Modern Studies 37.3 (2007), 534, https://doi. org/10.1215/10829636-2007-012. 
120 Action oder Bruch des Nachtmals: Gedechtnus oder Dancksagung Christi (Zurich, 1525) and Ein klare Underrichtung vom Nachtmal Christi (Zurich, 1526).

121 Lee Palmer Wandel, 'Envisioning God', 32.

122 Ibid, 33.

123 Rice and Pappano, The Civic Cycles, 20.

124 Johnston and Rogerson, eds, REED: York, 1.353, 11 22-3; see also Johnston, “'And how", 19-20.

125 Johnston and Rogerson, eds, REED: York 1.354, 11 22-3; see also Johnston, “'And how"', 20.

126 Johnston, “'And how"', 20.

127 Baldwin, Clopper, and Mills, eds, REED: Chester and Cheshire, 1.144, 11 22-5; qtd. in Johnston, “'And how"', 20.

128 Johnston, “'And how", 19.

129 Johnston and Rogerson, eds, REED: York, 1.390, 11 38-41. Johnston suggests that 'Perhaps the Council hoped that the new Archbishop, Edwin Sandys, would [in 1579] take a more flexible position than [previous Archbishop Edmund] Grindal' did in 1572 (“And how"', 20-1).

130 Eileen White, 'The Disappearance of the York Play Texts - New Evidence for the Creed Play', Medieval English Theatre 5.2 (1983), 106.

131 Davidson, 'Memory and Remembering', 348, n. 49.

132 Beadle, The York Plays, 1.xxii-xxiii. Johnston notes that when the manuscript resurfaced it was owned by the Fairfax family, which may suggest confiscation by Archbishop Sandys and/or Dean Hutton. William Fairfax at the time of the play's suppression belonged to the Council in the North with the archbishop and, with the archbishop and dean, to the northern Ecclesiastical Commission, two powerful governmental bodies whose inner circles consisted mainly of reformers; a second Fairfax, Thomas, belonged to the latter. For a discussion of the Fairfax family see Johnston, "'And how"' (13) and Toulmin Smith, York Plays (xii-xiii); for a discussion of the Council in the North and the Ecclesiastical Commission, their constitution and considerable powers, see Johnston, "And how"' (6-11).

133 Johnston and Rogerson, eds, REED: York, 1.392, 1.43-393, 11 1-4.

134 Qtd. in Michael O'Connell, The Idolatrous Eye: Iconoclasm and Theater in Early Modern England (New York, 2000), 26.

135 King, York Mystery Cycle, 175. 
